\title{
CARLO GOLDONI VE LOKANTACI KADIN ADLI YAPITINDA TOPLUMSAL ÖGELER
}

\section{Barış YÜCESAN*}

ÖZ: İtalyan tiyatro geleneği Avrupa tiyatro kültüründe önemli bir yere sahip olmakla birlikte XVIII. yüzyılda Commedia dell'arte'de yaşanan reformla birlikte tiyatro sanatının gelişimi de etkilenmiştir. XVIII. yüzyılda yaşamış olan ve tiyatroda bir devrim niteliği taşıyan değişiklikleri uygulayarak söz konusu değişikliklerin kabul edilmesine öncülük eden Carlo Goldoni olmuştur. Yapıtları ile tiyatro geleneğine köklü değişiklikler, diğer bir deyişle reform, getirmiştir. Önde gelen yapıtlarından biri olan Lokantacı Kadın adlı yapıtında içinde bulunduğu yüzyılın değerlerini, yani Aydınlanmacılığın da temel değerlerinden olan toplum kesimlerinin adaletli bir düzen içinde temsil edilmelerini, yaşamalarını ve eşitliği savunan değerlere rastlamak mümkündür. Yapıtın başkahramanı bir kadındır ve bu önemli özelliğiyle düşünce bağlamında içinde bulunulan dönemin ötesine geçebilmeyi başarır. Ayrıca başta başkahraman olmak üzere diğer karakterlerle birlikte aristokrat sınıfın eleştirisi yapılarak, kentsoylu sınıf, ticaret ile uğraşan ve zenginleșen zümre, övülür. Çünkü kentsoylu toplum aklını kullanarak aristokrasinin geri kalmışlı̆̆ıla alay eder. Yapıt bu sosyolojik ögeleri de barındırmakla kalmayarak metni olan, karakterleri değişebilen ve maskelerin kullanılmadığı bir reformcu tiyatro olarak Goldoni'nin bu sanata katmış olduğu değerleri ve yenilikleri içinde barındırır.

Anahtar Kelimeler: Goldoni, Commedia dell'arte, tiyatro, XVIII. yüzyıl, Lokantacı Kadın

\section{SOCIAL ELEMENTS IN THE MISTRESS OF THE INN OF CARLO GOLDONI}

ABSTRACT: The tradition of Italian theatre does not only have a significant place in the tradition of European theatre and also has affected the improvement of the art of theatre with the reform taking place at Commedia dell'arte in 18th century. Carlo Goldoni, living in the 18th century, became the pioneer in accepting the changes by implementing these revolutionary changes in theatre. With his works, he brought fundamental changes to the tradition of theatre, in other words, he made a reform. In The Mistress of the Inn, one of his pre-eminent works, it is possible to see the values of that century, which are to be represented, to live in justice and to support equality for different people from different walks of life, and these values are the most fundamental virtues of the Enlightment. The protagonist of the work is a woman and this becomes successful in going beyond the notion of the era with this important aspect. In addition, particularly with the protagonist and with the other characters, the aristocratic class

* Arş. Gör., Ankara Üniversitesi, Dil ve Tarih-Coğrafya Fakültesi, Batı Dilleri ve Edebiyatları Bölümü, İtalyan Dili ve Edebiyatı Anabilim Dalı, byucesan@ankara.edu.tr ORCID: https://orcid.org/0000-0002-1776-9815 
are criticized and bourgeois class, people dealing with trade and people becoming rich are praised. Because bourgeois society makes fun of with backwardness of the aristocratic class by using their mind. This work does not only include sociological elements but also includes the virtues and novelty which Goldoni contributed to the art of theatre as a reformist theatre that has a text, fluctuant characters and has no masks.

Keywords: Goldoni, Commedia dell'arte, theatre, XVIII. Century, The Mistress of the Inn

\section{Giriș}

İtalyan tiyatrosunda XVIII. yüzyılın ikinci yarısından itibaren kayda değer değişiklikler yaşanmaya başlanmıştır. $\mathrm{Bu}$ makalenin konusu tiyatrodaki değişimin İtalya'daki öncüsü olan Carlo Coldoni'nin Lokantacı Kadın yapıtı aracılığıyla söz konusu sanatta yaşanan gelişmelerin tematik bir biçimde incelenmesidir. Bunu yaparken kuşkusuz ünlü oyun yazarının pek çok yapıtı incelenebilirdi, fakat yazar üzerine yapılan diğer araştırmalar da incelendiğinde tekrara düşülmesi tehlikesine karşın, konunun daha daraltılmış bir çerçevede ve tek bir oyun üzerinden incelenmesi tercih edilmiştir. $\mathrm{Bu}$ makalede yalnızca XVIII. yüzyılda tiyatro sanatındaki değişikliklerin incelenmesi amaçlanmaz, aynı zamanda oyundaki toplumsal ögelerin belirtilmesi de hedeflenmektedir. Bu kapsamda Georg Lukács, Franco Ferrarotti ve Antonio Gramsci gibi edebiyat sosyolojisi üzerine çalışmış olan eleştirmenlerin savunduğu edebiyat ve sosyoloji ilişkisinin yadsınamaz bir şekilde yapıtlara yansıdığı tezinden yararlanılmıştır: Öyle ki, "Rönesans ve Aydınlanma Dönemi'ndeki edebiyat anlayışı demokratik bir dönüşümün öncüsü ve habercisi olmuştur. Söz konusu dönemlerde edebiyata sanat, politika ve ekonomi gibi sosyal hayatın farklı bileşenleri dâhil olmuştur." Buna ek olarak, Aydınlanma Dönemi'ne denk gelen bu çağda akıl ön plana çıkar. $\mathrm{Bu}$ gelişmelere kayıtsız kalmayan Goldoni de oyunlarında hem politik ve ekonomik güce sahip hem de toplumsal üretime yeterince katkı sunamayan ve büyük toplumsal değişimin eşiğinde olan Avrupa'da eski alışkanlıklarını sürdürmek isteyen toplumsal gerçeklikten uzaklaşan aristokrasi erkinin yaşam tarzını hicveder. Nitekim Lokantacı Kadın oyunu söz konusu toplumsal ögeleri barındırması bakımından zengin bir içeriğe sahip olduğu için makalenin konusunu oluşturmaktadır.

İtalyan tiyatro geleneği içinde önemli bir evreyi temsil eden Commedia dell'arte XVIII. yüzyılda yaşamış olan oyun yazarı Carlo Goldoni ile yalnızca İtalya'da etkili olmaz, aynı zamanda Avrupa'nın tiyatro sanatında

\footnotetext{
${ }^{1}$ Georg Lukács, "Lo scrittore e il critico" içinde Sociologia delle Letteratura, Mursia, Milano,
} 1977, s. 87. 
da derin izler bırakır: "Commedia dell'arte tuluat ve doğaçlama tekniğine dayalı XVI. yüzyll Italyan halk tiyatrosu geleneğinin bir biçimidir."”

Commedia dell'arte seyirciyi eğlendirmek amacını taşır. $\mathrm{Bu}$ nedenle doğaçlama tiyatrosunda karakterler ciddi ve komik olarak ikiye ayrılabilir ve söz konusu karakterler arasında öne çıkanlar komik olanlardır. Herhangi bir oyunu izleyenlerin oyundan ne kadar çok keyif aldıklarını ortaya koyan en temel gösterge oyuncuların performanslarını icra ederken seyirciden topladığı alkıştır. Komedinin izleyici açısından kusursuza yakın ve eğlenceli olması oyunun başarısını artırır. Öte yandan ise başarı ölçütlerinde oyuncunun rolü de kuşkusuz önemlidir ve oyuncunun oyun sırasındaki performansina da değinmek gerekir. Commedia dell'arte'de oyuncular yeteneklerini geliştirebilme ve farklı özelliklerini sahneye koyabilme hususunda kayda değer bir ilerleme gösteremezler, çünkü tiyatro oyuncuları kariyerleri boyunca yalnızca tek bir rolü canlandırır, diğer bir deyişle yeteneklerini tek bir karakterle sınırlandırırlar. Dolayısıyla o dönemin tiyatro oyuncuları modern anlamdaki tiyatro sanatına göre daha basit ve sığ kalırlar. $^{3}$

Doğaçlama komedisinin yazılı komediye dönüşmesine imkân veren Goldoni, tiyatro anlayışına yenilikler getirerek Commedia dell'arte'yi daha özgün kılar ve ona sanatsallık katar. Lakin bunu yaparken de Carlo Goldoni'nin tiyatroyu geliştirme ve değiştirme, diğer bir deyişle Commedia dell'arte'ye daha fazla saygınlık ve sanatsallık kazandırma çabası uzun zamandır oyunlarda gösterdikleri performansları alışkanlığın bir ürünü hâline getiren tiyatro oyuncuları tarafından kolay kolay kabul görmez. Buna rağmen Goldoni, sahneye getirmeye çalıştığı yazılı metinler, maskelerin artık kullanılmaması ve oyuncuların her rolü oynayabilmesi gibi yenilikleri tiyatro çevrelerine yavaş yavaş kabul ettirebilmeyi başarır. ${ }^{4}$

Goldoni'nin en çok bilinen tiyatro oyunlarından biri olan Lokantacı Kadın (La Locandiera) 1753 yılında yayımlanır ve o zamandan günümüze dek ülkemiz de dâhil Avrupa ve dünya tiyatrolarında sahnelenir. Bu bakımdan oyun geniş çevrelerce bilinmektedir. $\mathrm{Bu}$ durum Goldoni'nin uluslararası bir üne sahip olduğunun da bir göstergesidir. Söz konusu oyunla birlikte Goldoni izleyicilerin ilgisini sahnelere çekebilmeyi ve toplumsal yapıyı tüm çıplaklığıyla izleyicilere aktarabilmeyi başarır. Tiyatro

2 Özdemir Nutku, Oyunculuk Tarihi, Yap1 Kredi Yayınları, C. 1, İstanbul, 1995, s. 73.

${ }^{3}$ Edmondo Rho, "Carlo Goldoni", Letteratura italiana I Maggiori, ed. Carlo Marzorati, Dott. Carlo Marzorati, Milano, 1956, s. 497-498.

${ }^{4}$ Levent Suner, "Commedia Dell'Arte Etkisinde Üç Oyun Beş Yorum”, Tiyatro Araştırmaları Dergisi, 24, 2007, s. 156. 
sahnelerinde yaşanan tüm bu yenilikler toplumsal farkındalığ 1 artırmada yadsinamayacak derecede etkindir.

\section{Carlo Goldoni ve Commedia Dell'Arte}

XVIII. yüzyıl Avrupa açısından politik ve sosyolojik alan başta olmak üzere hayatın pek çok yönünde değişimlerin yaşandığı bir dönemdir. 1789 Fransız Devrimi hiç kuşkusuz yüzyılın en önemli tarihsel olaylarından biridir. Devrim gerçekleşmeden önce felsefe sanat alanındaki gelişmelerin Devrim'in habercisi olduğunu söylemek mümkündür. Akılcılık bu noktada önemli bir konuma sahiptir. Zira Aydınlanma döneminde Immanuel Kant, Jean-Jacques Rousseau, Thomas Paine gibi pek çok düşünür artık geçmişin değer yargıları ve gelenekselciliğinden vazgeçip, hem düşüncenin hem de toplumsal yaşam biçiminin değişikliklere uğraması gerektiğini savunarak bu süreçte rol oynamışlardır.

Söz konusu hususta İtalya özellikle de Goldoni’nin memleketi olan Venedik'teki duruma bakmak gerekirse Avrupa'da gerçekleşmekte olan politik ve toplumsal gelişmelerden derinden etkilendiği söylenebilir. Nitekim Cesare Beccaria, Pietro ve Alessandro Verri gibi topluma ayna tutan düşünür ve yazarların Aydınlanmacılık akımına dâhil oldukları düşünüldüğünde sosyal değişimlerin diğer bir ifadeyle Aydınlanmacı fikirlerin İtalya'ya da sıçraması kaçınılmazdır. Akıl toplum yaşamında daha ön plana çıkar. Bilimsel çalışmalara verilen değer artar. Kilise Devleti'nin karşı çıktığı pek çok yasaklı konu üzerine kitaplar yazılır. Felsefe alanında gelişmeler sağlanır. Bilimle ilgilenen kişi sayısı artar ve geçmişe nazaran bilim daha hızlı bir şekilde ilerlemeye başlar.

Avrupa'daki genel toplumsal durumu ifade ettikten sonra Venedikli oyun yazarı Goldoni'nin tiyatro sanatındaki yenilikleri hangi sosyolojik gerçeklikte yaptığını anlamak daha kolay olacaktır.

Goldoni İtalyan tiyatrosunun en tanınmış isimlerinden biri olmakla beraber gerek tiyatroya getirdiği yenilikler gerek yazdığı oyunlarla XVIII. yüzyılın tiyatro geleneği üzerinde derin izler bırakmıştır. Goldoni'den önce doğaçlamaya dayanan ve bir metne bağlı kalınmadan oyuncuların yüzlerine maske takarak oynadıkları ve ünlü Fransız tiyatrocu Molière için de esin kaynağ dell'arte), Goldoni'nin yapmış olduğu -o dönem için köklü ve yenilikçi olarak nitelendirilebilecek- bir değişimle farklı bir gelişme sürecine girer. $\mathrm{Bu}$ 
nedenledir ki kurumsallaşmış güçlü bir yapıya reform getiren "Goldoni Italya'nın en öncü oyun yazarıdır [...]".

Yenilikçi Goldoni'yi anlayabilmek için tiyatronun İtalyan yarımadasında geçirmiş olduğu tarihi sürece kısaca değinmek gerekir. Profesyonellerin doğaçlama yaparak ustalıklarını gösterdikleri İtalyan tiyatro geleneğini Ortaçağ döneminde kentlerin ve kasabaların meydanlarında şiirleri halka okuyan ve İtalyanca'da giullari olarak adlandırılan soytarılara dayandırmak mümkündür. Ortaçağ'ın sona ermesiyle başta İngiltere olmak üzere Avrupa'da yeni tiyatro eserlerinin verilmeye başlaması ve tiyatronun giderek önem kazanması Carlo Goldoni'nin yaşamış olduğu döneme kadar sürüp gelmiştir. Tiyatronun bu gelişim ve dönüşüm sürecinin farkına varan Goldoni, toplum nazarında da ilgi gören bu sanat dalında yeniliğe ihtiyaç duyulduğunu düşünür. Bahsi geçen dönem olan Ortaçağ'dan Commedia dell'arte'ye kadar geçen süreyi Edmondo Rho şu şekilde özetler: "Ortaçă̆'da, doğaçlama geleneği soytarılarla (giullari) canlı tutulmuştur, [...] Rönesans'ta Latinlerin Commedia erudita'yl (Commedia dell'arte'ye karşıt ve saray çevrelerinde oynanan tiyatro anlayışl) taklit etmesi, halk tiyatrosunun gelişimine katkı sağlamıştır. Harikulade bir şekilde doğa, profesyonellerin tiyatrosunu Commedia dell'arte 'yi yaratarak, üstün gelir."

Geçen zaman içinde siyasi gelişmelerin de değişime uygun bir ortam hazırlaması sayesinde aydınlar toplumsal ve kültürel değişimin öncülüğü rolünü üstlenirler. Aydınlanma Çağı olarak adlandırılan bu dönem Avrupa'da bilime verilen değer neticesinde gerçekleşen yeniliklerle ortaya çıkan yeni orta sınıfla birlikte kültürel değişimin, aklın ve bilimin ön planda tutularak insan yaşamıyla tam anlamıyla bütünleştirildiği bir dönemdir. Aydınların toplumsal gelişimi sağlama amacıyla üstlendiği bu görevin arkasında yeni bir toplum yaratma arzusunun olduğu şu şekilde açılanabilir: "XVIII. yüzyılın ortalarına gelindiğinde, siyasi gelişmelerin de etkisiyle köklü bir değişim sürecinde, kültür adamlarl, aydınlar, yeniden kendilerini sivil bir toplumun eğitimli ve sorumluluk sahibi üyeleri olarak gördüler; diğer bir taraftan da metne dayall, gerçekçi, ahlaki temeli olan tiyatronun yeniden doğuşunu kolaylaştırabilecek bir toplum yarattılar" ". Hayatın pek çok alanına yansımaya başlayan aydınlanmacı düşünceler belli bir oranda tiyatroya da yansır. Örneğin yapıtın başında yer alan "Yazardan Okura" adlı

5 Daniel Heartz, "Goldoni, Don Giovanni and the Dramma Giocoso", The Musical Times, 120, 1642, Londra, 1979, s. 993.

${ }^{6}$ Edmondo Rho, "Carlo Goldoni", Letteratura italiana I Maggiori, ed. Carlo Marzorati, Dott. Carlo Marzorati, Milano, 1956,s. 495.

${ }^{7}$ Franco Fido, Guida a Goldoni Teatro e società nel Settecento, Giulio Einaudi Editore, 1, Torino, 1977, s. 7. 
bölümde kaleme aldığı bu oyunun o güne kadar yazdıkları arasında toplum açısından en ahlaki, en yararlı ve en öğretici olduğunu savunur. Aydınlanmacıların kaygısının da topluma daha yararlı ve ahlaklı şeyler vermek ve toplumu eğitmek olduğu varsayıldığında Goldoni'nin bu amaca ne denli hizmet ettiği anlaşılır. Aynı şekilde içinde bulunduğu dönemin değerlerini yapıtında benimser ve toplumsal ihtiyaçlara cevap vermek için oyunlarını yazarken ihtiyaç duyduğu malzemeyi yaşamın kendisinden alır. Üstelik yaşam felsefesi olarak hayatı da komedi oyunlarına benzetir. "Onun için tiyatro insanlık hallerini yansitan bir sanat dalıdır."

Onun oyunlarında göze çarpan ortak noktalardan belki de en belirgini ve önemlisi şudur: oyunları mutlu sonla biten bir komedidir. Yaşamın güzel ve kötü anlarının iç içe geçtiği oyunlarında sonuç daima mutlu sonla biter. $\mathrm{Bu}$ özellik onun yaşama bakış açısıyla yakından ilintilidir. Tiyatronun geleneksel amaçlarından birinin halkı eğlendirmek, halkı bilgilendirmek olduğu düşünüldüğünde, tiyatro yazarı Goldoni'de yaşamın renklerini yapıtına katma çabası açıkça görülecektir. Bu noktadan hareketle "Goldoni için de yaşam güzeldir ve doğal döngüsü içinde yargılanır, duyguların coşkusu kazanır ki, orada sakin göllerde bile dalga olur: yaşamın mutlu sonla biten bir komedi olduğunu unutmamak kaydlyla". ${ }^{9}$

Bu bakış açısıyla yazarın tiyatro yazarken dikkat ettiği hususlar şunlardır:

Goldoni'nin oyunları gerçek yaşamdan esinlenilerek yazılmış olan ve özellikle burjuvanın sorunlarına odaklanan, kentsoylu sınıfın yer aldığı Venedik sokaklarında dolaşan oyunlardır. Goldoni için yaşam mutlu sonla biten bir komedi olmalıdır, bu nedenle oyunlarında gerçek sorunları aktarırken komik üslup benimsemeyi ihmal etmez. Burjuva sınıfının zenginliklere ve lükse olan düşkünlüğü, eski gelenekler ile bu yeni sınıfın yaşam tarzı arasındaki farklılıklar oyunlarında mutlaka yer alan konulardır. ${ }^{10}$

Venedikli oyun yazarı Goldoni sözlü tiyatro geleneğini yazılı metinlere taşımasıyla Aydınlanma dönemi felsefesi ışığında metinleri sanatsal açıdan daha değerli bir biçimde izleyiciye aktarma yolunu seçmiştir. Aydınlanmanın da savunduğu eşitlikçi değerler onun tiyatrosunda da görülmektedir. Tiyatro soyluların ve amaçsızca yaşayanların eleştirildiği bir

\footnotetext{
${ }^{8}$ Ebru Balamir, "İtalyan Aydınlanmasının Ünlü Tiyatro Yazarı Carlo Goldoni ve Tiyatro Reformu" içinde Batı Kültür ve Edebiyatlarında Aydınlanma, Ankara Üniversitesi Basımevi, 1, 2013, s. 104-105.

${ }^{9}$ Edmondo Rho, “Carlo Goldoni”, Letteratura italiana I Maggiori, ed. Carlo Marzorati, Dott. Carlo Marzorati, Milano, 1956,s. 498.

${ }^{10}$ Ebru Balamir, "Commedia Dell'arte, Tiplemeler ve Carlo Goldoni ile İtalya'da Tiyatro Reformu”, RumeliDe Dil ve Edebiyat Araştırmaları Dergisi, 9, 2017, s. 87.
} 
mecra hâline dönüşür. Ayrıca belirtmek gerekirse aristokrat sınıfı geçmişe nazaran daha fazla güç kazanamasa da var olan gücünü elinde tutmaya çalışır. Nitekim oyundaki Markiz ve Kont karakterleri içinde bulundukları gülünç durumdan kurtulabilmek için unvanlarını ve toplumdaki konumlarını kullanmaya çalışırlar. Lakin söz konusu karakterler toplumun sorununu yansitmazlar, onlar hicve konu olan karakterlerdir. Hâlbuki Goldoni tiyatrosunda halkın gerçek sorunları konuyu oluşturur. Bu gelişme sanat ve halk yaşamının kucaklaşmasına neden olur ki, böylece sanat tabana da ulaşmaya başlar. Tiyatroyu bu denli başkalaşım içine sokma çabasının onun bu değişimi görev olarak üstlenmesiyle ilgili olduğu şu şekilde açıklanabilir:

Goldoni, İtalyan komedyasına yazılı oyunu getirmiştir; Commedia dell'arte'nin geleneksel doğaçlama/oyun çıkarma tekniğinden, maske takmış figürlerinden özgürce sergilenen fiziksel düşüp kalkma/itiş kakıştan vazgeçilmiştir. Bununla birlikte Commedia dell'arte'nin malzemesinden vazgeçmeyerek ilk defa İtalyan günlük yaşamının ve İtalyan insanının davranışlarının sanatsal olarak ele alınmaya elverişli olduğunu savlamış, entrika komedyası yerine gerçek hayatı yansıtmanın bir yazar olarak görevi olduğuna inanmıştır. ${ }^{11}$

Gerçekleştirmiş olduğu tiyatro reformu yazarın bazı olumsuz ve sert eleştirilere gögüs germek zorunda kalmasına neden olmuştur. Uzun süredir var olan bir düzene karşı yenilikçi tarzı benimsemek, pek çok eleştirmen tarafindan ona doğrultulan eleştirilerin nedenini oluşturur ve söz konusu eleştirilere yanıt verme zorunluluğunu doğurur. Goldoni'nin en çok eleştirildiği konulardan biri geleneksel İtalyan tiyatrosunun maske ve doğaçlama gibi çok önemli ögelerinin değerini yitirmesine neden olduğudur. $\mathrm{Bu}$ hususta "Commedia dell'arte'yi eleştiren eleştirmen Carlo Gozzi, Goldoni'nin düzenli ve inanılabilir metinleriyle şanl geleneksel Italyan maske ve doğaçlama tiyatrosunu değiştirmesinden dolayı onu suçlar." 12 Commedia dell'arte'nin kendine has özellikleri reform sonucunda önemini yitirir ve bu dönüşüm tiyatronun özgürlüğünün elinden alındığı savına kadar dayanır. Bu tür eleştiriler günümüz eleştirmenlerince de yapılmaktadır.

Venedikli yazar hakkında yapılan eleştiriler çift yönlü etki yapar: onu sadece zor durumda bırakmamışırı, aynı zamanda adından daha çok söz edilmesi nedeniyle bir anlamda sanat çevrelerinde tanınır hâle gelmesine yardımcı olmuştur. Hakkında yapılan eleştiriler tiyatroda yapmak istediği köklü değişikliklerin daha çok insan tarafından fark edilmesine ve

11 Levent Suner, "Commedia Dell'Arte Etkisinde Üç Oyun Beş Yorum”, Tiyatro Araştırmaları Dergisi, 24, 2007, s. 156.

${ }^{12}$ Franco Fido, "Goldoni oggi", Italica, 83, 3/4, 2006, s. 707. 
kanıksanmasına olanak sağlamıştır: "Goldoni'nin bu yenilikçi tavrı birçok dönem oyun yazarının ona karşı çıkmasına neden olmuştur. [...] Bu sikıntılı dönem Goldoni için tam tersine yararlı olmuştur. Düşüncelerini daha da netleştirmesini ve derinleştirmesini sağlamıştır". ${ }^{13}$ Kendisine yöneltilen eleştirileri de dikkate alarak düşüncelerini daha sağlam bir zemine oturtmayı başaran ve her zaman gelişime açı olan Goldoni, sonraki yapıtlarında da yenilikçi tavrını devam ettirmeyi başarır. Ancak yazar " [...] her ne kadar bir yeniliği başlatmış olsa da, komedilerinde doğaçlama tiyatrosunun izlerini tamamen yok edememiştir". ${ }^{14}$ Doğal olarak yüzy1llarca süren köklü bir geleneğin bir anda ortadan kaldırılabilmesi veya görmezden gelinmesi çok mümkün değildir. Özellikle de gelenekselden yeniye geçişte geçmişe ait bazı özelliklerin varlığını sürdürdügünü unutmamak gerekir. Bu durumun oluşmasında diğer bir etken ise Goldoni'nin yaşamını tiyatro oyunları yazarak kazanmasıdır. $\mathrm{Bu}$ nedenle, yazdığı oyunları tiyatro sahiplerinin isteklerine ve halkın taleplerine göre de şekillendirmesi zaruri bir durum hâline gelir. Tiyatroya getirilmek istenen yeniliğin tam anlamiyla sahnelere uygulanabilmesi nispeten uzun bir süreç gerektirir. Buna karşın Goldoni, nihayetinde hedeflediği gibi tiyatroya yenilik getirebilmeyi başarır.

Goldoni’nin tiyatroda yaptığı yeniliğe karakterler üzerinden de değinmek gerekir. Geleneksel İtalyan tiyatrosu karakterler bağlamında incelendiğinde, şu özellikler belirir: Tiyatroda karakterler hep aynıdır, aynı oyuncuların oynadığı aynı karakterler yaşamın gerçekliğinin gerisinde kalarak farklı sınıflara mensup halkın oyunda kendine ait izler bulamadığı bir hâl alır. Bu da yüzeyselliği beraberinde getirir. Karakterler üzerine özel bir çalışma yoktur, kısaca Goldoni'den "önceki hiçbir yapıtta karakterler üzerine bu kadar durulmaz veya sosyal sinfflar sahnede yer almaz". ${ }^{15}$

Yapıtlarının başarı elde etmesinin önemli sebeplerinden biri de gündelik hayatı seyirciye aktarma biçiminin oldukça sade ve net olmasıdır. Oyunlarını okuyan veya sahnede izleyenlerin kendi yaşamlarında da kolaylıkla bulabilecekleri benzerlikler, onların oyunu daha iyi kavramalarına ve oyunun etkisi altında kalmalarına neden olur. Zira izleyiciler sahnede olup bitenleri ve karakterleri kendilerinden bir parça gibi gördüklerinden, sahne onlar için âdeta ayna görevini görmeye başlar, yani sanatın toplum için ayna görevini görme özelliği tiyatronun yaşamın içinden ögeleri barındırmasıyla örtüşür. Üstelik daha önce değinildiği üzere, İtalyan oyun yazarının gündelik hayatı

${ }^{13}$ Ebru Balamir, "İtalyan Aydınlanmasının Ünlü Tiyatro Yazarı Carlo Goldoni ve Tiyatro Reformu" içinde Batı Kültür ve Edebiyatlarında Aydınlanma, Ankara Üniversitesi Basımevi, 1, 2013, s. 102

${ }^{14}$ E. Balamir, a.g.m., s. 105 .

${ }^{15}$ Daniel Heartz, a.g.m., s. 993. 
sahneye aktarabilme başarısı tiyatro seyircisinin de kendini oyunun karakterleriyle özdeşleştirebilmesini kolaylaştıran bir etmen olmuştur. Tüm bunlardan anlaşılacağı üzere, Goldoni'nin tiyatro alanındaki yenilikçi tutumu Avrupa'nın da dikkatinden kaçmaz ve böylece Goldoni kaleme aldığı oyunlarla özgün olmanın yanında evrenselliği de yakalamayı başarır:

Özgünlügü özellikle de mükemmel olarak teatral durumları aktarabilme kapasitesinde olduğunu söylüyordum, bu yüzden bir yandan gündelik olay, diğer bir ifadeyle gazetecilik dili, insan davranışlarının geniş görüngüsüne yoğunlaşır, örnek bir değer ortaya koyar, eğer büyük laf etmek istersem, evrensel derim, herkesin kendini tanıyabileceği bir ayna olur; diğer yandan genel konularda biraz yerel kullanıma kaçar, acı, endişe yerel ve gündelik bir konuda inandırıcılığı artırıyor ve ilgiyi topluyor. ${ }^{16}$

Carlo Goldoni üzerine önemli araştırmalarda bulunmuş olan Silvio D'Amico onun hakkında şu değerlendirmelerde bulunarak Goldoni'nin sanat, toplum ve dolayısıyla yaşam üçgeninde ne gibi bağlar kurduğunu aktarır: "Goldoni tiyatroya ait, XVIII. yüzyılın adamıdır, karşıttır, realizm karşıtıdır: Goldoni tiyatrosu, yaşam ve tiyatro arasindaki mutlu aktarımin eşsiz meyvesidir, ĕger dünyanın demek çok iddialı olacaksa da en azından İtalya'nin tiyatroya en meyilli şehrinde meydana gelmiş, önce tiyatroyu sonra yaşamı araştırmış, sanat ve insanlık iliş̧isini görmüşü̈r". ${ }^{17}$

Tiyatroya kattıkları düşünüldüğünde sanatın gelişimine büyük yarar sağlayan Goldoni'yi yaşadığı dönemin öncüsü olarak değerlendirmek abartı olmayacaktır. Dönemin Venedik Cumhuriyeti'nin içinde bulunduğu zorlu siyasi şartlar hesaba katıldığında, yazdıklarıyla o zamanın toplumsal özelliklerini, siyasi ve ekonomik şartlarını yapıtlarına yansıtabilmiş ve bu başarısını sanat çevrelerine kabul ettirebilmeyi başarabilmiş bir sanatçı olarak yapıtları günümüzde de geçerliliğini koruduğundan onun ne denli başarılı bir oyun yazarı olduğunu anlamak mümkündür.

Ayrıca XVIII. yüzyıl toplumunun -özellikle kadının toplumsal yaşamdaki rolü başta olmak üzere- pek çok yönünü oyunlarına yansıtmayı başarabilen Goldoni, Lokantacı Kadın oyunuyla da sınıfsal farkları ve toplumun değer yargılarını karakterlerinin diyaloglarında açıkça ortaya koymaktadır. Oyun, eleştirmenlerce oldukça beğenilir. Toplumsal yapının açık bir biçimde ortaya koyulabildiği yapıtta, kadın figürü de önemli bir yer tutmaktadır. Soylu sınıf ile kentsoylu sınıfın bir araya geldiği bu oyunda, Markiz, Kont, Şövalye ve

\footnotetext{
${ }^{16}$ Franco Fido, "Goldoni oggi”, Italica, 83, 3/4, 2006, s. 709.

${ }^{17}$ Edmondo Rho, "Carlo Goldoni”, Letteratura italiana I Maggiori, ed. Carlo Marzorati, Dott. Carlo Marzorati, Milano, 1956, s. 525.
} 
Mirandolina'nın düşünceleri üzerinden $\mathrm{o}$ dönem toplumunun değer yargılarını anlama şansı elde edebilmektedir.

\section{Lokantacı Kadın}

Lokantacı Kadın adlı tiyatro oyunu Goldoni'nin en tanınmış yapıtları arasında yer alır. Aydınlanmacı dönemde yazılan bu yapıt o dönemin önde gelen ozanlarından Giuseppe Parini'nin Il Giorno adlı yapıtıyla da soylu sınıfın eleştirilmesi bağlamında benzerlik gösterir. Toplumsal sınıfların öne çıktığı ve toplumsal çekişmelerin yoğun bir şekilde yaşanmaya başlandığı, diğer bir ifadeyle Fransız Devrimi'nin habercisi olan toplumsal gelişmeler ve dönüşümlerin yoğun olduğu bu dönemde, Goldoni'nin sınıfsal cepheleşmeyi oyunun arka planında yansıtması toplumsal yaşama kayıtsız kalmayan yazar için kaçınılmazdır. Lokantacı Kadın yapıtı ile Goldoni tiyatro reformunun karakteristik özelliği olan toplumu topluma anlatarak eğitici olma çabasını dışa vurabilmeyi başarır.

Oyundaki karakterler Goldoni'nin diğer yapitlarındaki karakterlerin genel çerçevesini oluşturur. 1753 yılında yazılan ve aynı yıl ilk kez sahnelenen bu oyun, günümüzde de tiyatro sahnelerinde zaman zaman oynanmaktadır. “Carlo Goldoni’nin komedileri bugün de kendi zamanındaki kadar beğenilir ve onun 70'ten fazla olan oyunu XVIII. yüzyıl komedi operasinın gelişimi üzerinde önemli etki bırakır."18

Lokantacı Kadın oyunu üç bölümden oluşur: İlk bölümde Mirandolina genç, güzel ve başarılı bir kadındır. Öyle ki, müşterisi olan iki soylu Forlipopoli Markizi ve Albafiorita Kontu onu elde etmeye çalışmaktadır. Olayın geçtiği yer Floransa yakınlarında bir yerleşim merkezidir. Markiz Mirandolina'yı tavlamaya çalışırken unvanına o kadar çok güvenmektedir ki, onu tavlayabilmek için özel bir çaba göstermesine gerek olmadığına, unvanının istediği her şeyi elde edebilmesine olanak sağladığına inanır. Markiz'in bu düşüncesi XVIII. yüzyıl toplumundaki sınıfsal ayrıma ve sınıflar arası güç farkına işaret etmektedir. Mirandolina'yı elde etmek isteyen bir diğer kişi olan Kont üzerinde durmak gerekirse, o da sevdiği kadının gönlünü pahalı hediyelerle fethedebileceğini düşünmektedir. Bir tarafta para, diğer tarafta ise makam ve unvan istenilen her şeye ulaşabilmenin anahtarı olarak görülmektedir. $\mathrm{Bu}$ sahnelerin arkasında Venedik Cumhuriyeti'nin yöneticisi olan aristokrat sınıfın anlaşmazlıkları, kendi aralarındaki siyasal kavgaların ve sosyal eşitsizliğin neden olduğu rahatsızlık yazar tarafindan ortaya koyulmaktadır. Kisaca belirtmek

\footnotetext{
18 Ted Emery, “Goldoni’s Pamela from Play to Libretto", Italica, 64, 4, 1987, s. 572.
} 
gerekirse, Kont ve Markiz karakterlerinin Mirandolina için birbirleriyle kavga etmeleri dönemin aristokrat sınıfının gerçekliğini yansıtmaktadır.

Yapıtın daha ilk sahnelerinde o yüzyılın insanlarındaki düşünce yapısı yansıtabilmiştir. Daha önce de değinildiği üzere, aynı dönemin ozanı Giuseppe Parini'nin şiirlerinde tıpkı Goldoni'de olduğu gibi toplumun aristokrat sınıfını alaycı bir üslupla eleştirdiğini görmek mümkündür. Buna örnek olarak Parini'nin Il Giorno adlı yapıtındaki şu dizeler gösterilebilir:

Kendini fazla düşündün; ya da kısa bir süre

sana yakışmayan

Bir nedenle kendi içine kapandın. Bilirsin Tanrı'nın

Genç efendiye bahşettiği

Büyük ve şanlı zaferler senin bir parçandır.

Tükeniyor musun?

$[\ldots]$

Ruhunu pahalı hediyeler güzelleştiremez,

Çünkü kaçınmalısın senin soylu yaşamının ortasında

Önüne set çeken

Yüksek zümreden ${ }^{19}$

İki önemli karakterin karşısına başka önemli bir karakter daha koyan Goldoni, Ripafratta şövalyesini oyuna dâhil eder. İlk karşılaşmalarında şövalyenin kendisine karşı ilgisiz ve küçümseyici bir gözle baktığını sezen Mirandolina, kendi içinden, kadınlara karşı pek de hoş davranmayan ve onlarla aşk yaşamaktan uzak duran bu şövalyeyi elde etmeye ant içer. Bu sahneden sonra olaylar daha da ilginç ve sürükleyici bir biçimde gelişmeye başlar.

Önemli bir husus da Mirandolina'nın işlettiği lokantaya yazarın vermiş olduğu özelliktir. Söz konusu lokanta farklı sosyal sınıfların bir araya geldiği nadir yerlerden biridir. Yani denilebilir ki, sosyal sınıf fark1 nedeniyle normal şartlarda bir araya gelemeyecek insanların hanlar aracılığıyla aynı ortamda bulunmaları o insanların doğrudan iletişime geçmelerine olanak sağlar. Diğer bir deyişle, Mirandolina'nın lokantası farklı sosyal sınıfa ait olan karakterlerin detaylı bir şekilde incelendiği laboratuvar gibidir.

İkinci sahneye gelindiğinde ise, kadınlar tarafından asla tavlanamayacağını ileri süren ve bunun farkında olan Mirandolina'nın hedefi olan Şövalye onu baştan çıkarmayı kafasına koymuş olan kadının tuzağına düşmekten kurtulamaz. Şövalyeyi tavlayan lokantacı kadın ona istediklerini yaptırır ve kendince ona hayatının dersini verir. Ondan intikam alabilmek

${ }^{19}$ Giuseppe Parini, Il Giorno, Feltrinelli, Milano, 1980, s. 33. 
için girdiği bu türlü oyunların sonunda başarıya ulaşır. Olay örgüsüne ek olarak, bu bölümde karakterlerin kişisel özellikleri ve toplum içinde yansıttıkları sınıfsal özellikleri genel anlamda yapıtın önemli bir amacı olan aristokrasinin eleştirisi yapılır.

Son sahnede olaylar Mirandolina'nın planladığı gibi gelişmeye devam eder. Şövalye ona aşkını ilan eder ve ona âşı olan diğer iki karakter ise Mirandolina'ya olan aşklarına yanıt bulamayınca lokantayı terk ederler. Bu yenilgi belki de aristokrasinin kentsoylu sinif ile olan mücadelesindeki yenilginin ilk işaretedir. Hedefine ulaşan Mirandolina daha önce söz verdiği üzere, Fabrizio ile evleneceğine ve bir daha insanları sevme bahanesiyle kandırmayacağına dair ant içer. Oyunun sonundaki bir monologda kadınların gücünden bahseder ve kendisinin yaptıklarını erkeklerin unutmamasını, erkeklere türlü oyunlara ve kurnazlıklara yem olmamasını öğütler.

Lokantacı Kadın adlı yapittaki diyaloglarda yazar, o dönemin toplumunun düşünce yapısına yönelik bazı ipuçlarını verebilmeyi başarır. Örneğin; soyluların toplum üzerindeki gücünü yansıtan şu diyalog dönemin sosyal-kültürel genel çerçevesini anlayabilmek açısından dikkate değerdir ve söz konusu diyalog içinde topluma yönelik çok daha fazla bilgiyi barındırır. "Ben önemli biriyim. Mirandolina'nın bana ihtiyacı var. Onu korumam altına almalıyım." 20 Markizin burada kurduğu cümle aslında sadece diyalogda geçtiği anlamında değildir. Daha derin anlamları içinde barındırır. Örneğin; bu cümle ile okuyucuya ve seyirciye dönemin zengin ve soylularının kendilerini toplumun üzerinde gördüklerine dair fikirler verilmektedir. Onlar için paraları ve unvanları, geçmişten de gelen bir özellik olarak, pek çok şey üzerinde hüküm sürmeye ve kararlar almaya yeter.

Diğer bir sahnede ise Fabrizio'nun Kont'a söylediği şu cümle, maddi gücün o dönemde de söz sahibi olabilmek için en önemli etkenlerden biri olduğunu göstermektedir. "[...] yabancı bir yerde insanın unvanına değil, cebindeki paraya bakarlar." 21

Goldoni, karakterlerin ağzından döneme ilişkin değerli bilgiler paylaşmaktadır. Özellikle de soylu sınıfın bir üyesi olan Markiz'in söyledikleri, soylu sinıfin toplumdaki konumuna ve ne gibi düşüncelere sahip olduğuna ilişkin notlar düşmektedir. Örneğin Markiz'in kullandığ 1 şu cümleler buna verilebilecek en güzel örneklerdendir:

${ }^{20}$ Carlo Goldoni, Lokantacı Kadın, İş Bankası Kültür Yayınları, İstanbul, 2015, s. 8.

${ }^{21}$ C. Goldoni, a.g.e., s. 11. 
"-Ah zavall Forlipopoli Markizi. Taklit diye verdim, on iki zecchino değerinde altınmış. Nasıl çıkacağım bu işin içinden. Kontesten hokkayı geri istesem onun gözünde küçük düşerim. Mirandolina benim aldığımı ögrenirse onurum kırllır. Ben bir soyluyum. Bedeli neyse ödemek zorundayım. Ama param yok [... ]". ${ }^{22}$

“-Peki hokka işi ne olacak? Bir soyluyum, hata yapamam [...]."23

Oyunun sonlarına doğru karakterlerin çıkarcılığı daha çok ön plana çıkar. Sosyal sınıflar arasındaki çıkar çatışmaları aynı şekilde karakterlerin diyaloglarında da yer alır. Goldoni'nin yazdığ 1 oyunun en göze çarpan özelliklerinden biri olan sınıfsal çıkar çatışmalarını yansıtması, bir anlamda Fransız Devrimi'ne giden süreçte topluma dolaylı veya doğrudan verdiği ince bir mesajdır. Şövalyenin diyaloğunda geçen şu cümle ilişkilerin çıkarlar üzerine kurulduğunun bir kanıtıdır: "[...] - Böyle bir evlilikle özgürlügümü tehlikeye sokmadan adımı sanımı ve çıkarlarımı koruyabilirim." 24

Carlo Goldoni oyunun başında yazdığı giriş bölümünde şu açıklamay1 yaparak yapıtıyla neyi amaçladığına dair okuru bilgilendirmek ister: "Güzel bir ayna koyduğumu sanıyorum gençliğin önüne." 25 Oyunun giriş bölümünde yazılan ve son bölümde Mirandolina'nın söylediği şu cümle birbirini tamamlar niteliktedir:

“-Bu sözlerinizden içtenlikle ve olabildiğince mutlu oldum. Medeni halimle birlikte tavır ve davranışlarımı da değiştireceğim... Siz siz olun beyler, kalbinizin iyiliği ve sağllğ için burada gördüklerinizden yararlanmayı unutmayın; tuză̆a düşmek, oyuna gelmek gibi olasılıklar karşısında buradaki kurnazlıkları, ayak oyunlarını düşünün ve lokantacınız Mirandolina'yı aklınızdan hiç mi hiç çıkarmayın!"26

Lokantacı Kadın'da bir kültür çatışması da yansıtılmaktadır. Oyundaki markiz, kont ve şövalye karakterleri antik rejimin değer yargılarını temsil ederken, lokantacı kadın olan Mirandolina Aydınlanma dönemiyle gelişmekte olan ve Sanayi Devrimi ile sonrasında yaşanacak olan modern zamanların bir habercisi olarak kadının toplumdaki yerine dair derin bir mesaj içermektedir. Bunu Franco Fido'nun Goldoni ve yapıtları üzerine yazdığı şu değerlendirmede de görmek mümkündür: "Dışa kapalı şüpheci ve acımasız burjuva karakterinin arkasında ciddi bir tartışma yatıyor. Lokantacı Kadın'da olduğu gibi, Mirandolina'nın soyluların karşısındaki

${ }^{22}$ C. Goldoni, a.g.e., s. 125.

${ }^{23}$ C. Goldoni, a.g.e., s. 127.

${ }^{24}$ C. Goldoni, a.g.e., s. 130.

${ }^{25}$ C. Goldoni, a.g.e., s. 2.

${ }^{26}$ C. Goldoni, a.g.e., s. 148. 
oyunu ve gülünç âşıkları antik rejimin önyargısı ve modern bağımsız bir kadının çalışması üzerine kurulan iki kültür arasındaki derin çatışmayı yansıtır." $27 \mathrm{Bu}$ çatışmayı kazanan yenilikçi düşüncenin temsilcisi denilebilecek Mirandolina'dır. Aslında Goldoni'nin yapmaya çalıştığı, tiyatroda yaptığı reformların başarıya ulaşacağını başkahramanı aracılığıyla topluma göstermektedir.

Goldoni'nin bu oyunuyla ilgili söylenebilecek bir diğer husus da, yapıtın başından sonuna kadar düşünce aktarımı ve olay örgüsü bağlamında tutarlılık sergilemesidir. İtalyan oyun yazarı ortaya koymak istediği düşünceleri kronolojik sırayla ve tutarlı bir mantık çerçevesinde ortaya koyarak sonuca ulaşmayı başarır.

$\mathrm{Bu}$ nedenledir ki "Goldoni'nin tiyatrosu yadsınamaz biçimde toplumsal içeriklidir ve toplumcu gerçekçiliğin somut örneklerindendir." ${ }^{28}$ Diğer bir yandan ise, Goldoni'nin bu tutumuyla yüzyılının kozmopolit düşüncelerini ortaya koyabilmeyi başaran birkaç aydından biri olduğunu söylemek yanlış olmayacaktır. Üstelik bunu yaşadığı yüzyılın tüm zorluklarına rağmen başarabildiği şu değerlendirmeden anlaşılır:

Carlo Goldoni reformunu aşılması büyük zorluklara rağmen- her türde: tiyatro, edebi, sansürlenen ve hatta ideolojik- tiyatro tarihinde yer almayan bir tutarlılık ve süreklilikle devam ettirebilmeyi başardı. Diğer bir taraftan, Goldoni'nin onu Voltaire ve Mozart'a yaklaştıran bir yanı var: Bu üç sanatçı da farklı derecelerde 1800'lü yılların Avrupa kozmopolitizminin özünü açıklamaktadırlar. ${ }^{29}$

Lokantacı Kadın toplumsal katmanları yansitan tiyatro yapitı olmas bakımından da türünün başarılı bir örneği olarak adlandırılabilir. Tiyatronun günümüzdeki genel mantığına bakıldığında toplumsal gerçekleri yansıtan ve toplumu bu konuda uyarma, ona farklı bir ileri görüşlülük katabilme amacı ile örtüştüğü söylenebilir. Kadın karakterin bu kadar ön plana oturtulması yeniliğin içinde yenilik olarak da adlandırılabilir. Goldoni’nin ortaya koyduğu, zamanına göre cesaret gerektiren ve gerçeklik üzerine kurulu yapıtları Commedia dell'arte'nin değişimine ön ayak olan etmenlerdir.

Yapıtın Goldoni’nin XVIII. yüzyılın kentsoylu sınıfının düşünce yapısını, yaşam biçimini ve toplum içindeki konumunu en iyi aktaran oyunlarından yeterli biri olarak değerlendirildiğini Öncel şu şekilde açıklamaktadır:

\footnotetext{
${ }^{27}$ Franco Fido, "Goldoni oggi”, Italica, 83, 3/4, 2006, s. 713.

${ }^{28}$ Carlo Goldoni, Lokantacı Kadın, İş Bankası Kültür Yayınları, İstanbul, 2015, s. VII.

${ }^{29}$ Franco Fido, Guida a Goldoni Teatro e società nel Settecento, Giulio Einaudi Editore, 1, Torino, 1977, s. 49.
} 
Denilebilir ki komedilerinin belirgin özelliği gerçekçi olmaları ve burjuva toplumunu yansıtmalarıdır. $\mathrm{Bu}$ açıdan incelenebilecek güzel bir örnek Locandiera'dır. Oyunun başkahramanı olan pansiyoncu kadın Mirandolina müşterilerinin başını döndürmekten zevk alır, ama sonunda kendisine kur yapan soyluları başından savarak uşak Fabrizio'yu kendine eş seçer. ${ }^{30}$

Lokantacı Kadın'da yozlaşmış aristokrat sınıfın yani, ülkenin geleceğinden ziyade kendi ihtirasları peşinden koşanların hikâyesi anlatılır. Bir nevi Goldoni topluma gerçekleri ve onları yönetenlerin ne gibi işlerle meşgul olduğunu göstererek, sanatçının halka gerçekleri aktarma görevini yerine getirmiştir. Lakin tüm uyarılara rağmen yöneticilerin birliği sağlayamamas1, Venedik Cumhuriyeti'nin 1797 yılında AvusturyaMacaristan İmparatorluğu egemenliği altına geçmesine neden olur.

\section{Sonuç}

Carlo Goldoni'nin I Mémoires (Hatıralar) adlı özyaşamöyküsel yapıtına bakıldığında, Lokantacı Kadın gibi pek çok yapıtında yarattığı karakterlerin yaptığ gaflar, aslında onun yaşamında var olan kişilere aittir ve bu durum onun çevresini ne kadar iyi gözlemleyebildiğinin kanıtıdır. Goldoni'nin yapitları farklı sosyal sınıfların bir araya geldiği bir ortamdaki gündelik yaşamı yansıtır ve bunun sağlaması, aslında, oyunlarının kendi yaşamının bir ürünü olduğunu bilmekten geçer.

Her ne kadar oyun, Commedia dell'arte'ye bir yenilik getirse de, eski gelenekten tam anlamıla kopamamıştır. Bazı özellikleri hâlâ geleneksel doğaçlama tiyatrosunun özelliklerini taşımaktadır.

İtalyan tiyatrosuna getirdiği yeniliklerle Goldoni yalnızca XVIII. yüzyılın değil aynı zamanda günümüzün de gelmiş geçmiş en değerli oyun yazarlarından biri olarak kabul edilmektedir. Tiyatroyu ve yaşamı buluşturması toplumun kendini bir nevi onun yapıtlarında bulmasına neden olur. Goldoni'nin oyun yazımında en öne çıkan özelliklerinden biri de budur.

Goldoni, bu oyununda, mensubu olduğu kentsoylu sınıfın sosyal hayatta nasıl bir konumda olduğunu göstererek sadece kentsoylu tabakanın önüne ayna tutmakla kalmaz, aynı zamanda toplumun diğer tabakalarıyla olan ilişkilerini de gözler önüne serer. XVIII. yüzyılda doğup beslenmeye çalışan Aydınlanma Çağı ile örtüşen sosyal tabakaları gözler önüne serme, gerçekçi olma ve akılcı bir tavır sergileme gibi yüzyılın değerleri Goldoni'nin oyununda vücut bulmuştur.

Venedik Cumhuriyeti'nin son yıllarında yazılan bu oyunda yönetici sınıftaki anlaşmazlığın, tartışmaların, halkın gerçek durumunun yöneticiler

${ }^{30}$ Süheyla Öncel, İtalyan Edebiyat Tarihi 2. Kitap, İtalyan Kültür Heyeti, Ankara, 1998, s. 32. 
tarafından yeterince dikkate alınmadığının yansımaları görülür. Markiz, Kont ve Şövalye yönetici sınıfi temsil eder ve yazar tarafindan zamanın gerisinde kalmış insanlar olarak değerlendirilirler.

Dönemin ekonomik yaşamı da bir ölçüde oyun aracıllı̆ıyla gözler önüne serilmektedir. Aristokrat sınıfa mensup birinin nakit sıkıntısı çekmesi de aristokrat sınıfın yavaş yavaş güç kaybettiğinin bir göstergesidir. Tüm bu hususlar düşünüldüğünde oyunun sosyal yaşamın bazı özelliklerini yansıttığı söylenebilir.

Son olarak ise, Lokantacı Kadın başkahramanı kadın olan bir oyun olarak İtalyan edebiyatının doğduğu XIII. yüzyıldan başlamak üzere aralarında bazı farklar olsa da temelde Dante, Petrarca, Boccaccio gibi İtalyan edebiyatının büyüklerinin önemli yapıtlarının izlerini taşıdığı söylenebilir. Denilebilir ki, bir anlamda Goldoni de bu yazarların izinden giderek kendisini yapıt verdiği tiyatro alanında ölümsüz kılabilmeyi başarmıştır.

\section{KAYNAKÇA}

Balamir, Ebru, "İtalyan Aydınlanmasının Ünlü Tiyatro Yazarı Carlo Goldoni ve Tiyatro Reformu", Batı Kültür ve Edebiyatlarında Aydınlanma ed. Battal Arvasi. Ankara Üniversitesi Basımevi, Ankara, 2013.

, “Commedia Dell'arte, Tiplemeler ve Carlo Goldoni ile İtalya'da

Tiyatro Reformu”, RumeliDE Dil ve Edebiyat Araştırmaları Dergisi 2017/9, 2017, 81-88.

Emery, Ted, "Goldoni's Pamela from Play to Libretto", Italica, 64(4), 1987, 572582.

Fido, Franco, Guida a Goldoni Teatro e società nel Settecento, Giulio Einaudi Editore, Torino, 1977. , “Goldoni oggi", Italica, 83(3/4), 2006, 707-716.

Goldoni, Carlo, Lokantacı Kadın, Türkiye İşBankası KültürYayınları, İstanbul,2015.

Heartz, Daniel, "Goldoni, Don Giovanni and the Dramma Giocoso", The Musical Times 120(1642), 1979, 993-998.

Lukács, Georg, "Lo scrittore e il critico", Sociologia della Letteratura ed. Alfredo Luzi, Mursia, Milano, 1977.

Nutku, Özdemir, Oyunculuk Tarihi, Yapı Kredi Yayınları, İstanbul, 1995.

Öncel, Süheyla, Ittalyan Edebiyat Tarihi 2. Kitap, İtalyan Kültür Heyeti, Ankara, 1998.

Parini, Giuseppe, Il Giorno, Feltrinelli, Milano, 1980.

Rho, Edmondo, "Carlo Goldoni", Letteratura Italiana I Maggiori ed. Carlo Marzorati, Dott. Carlo Marzorati, Milano, 1956. 
BARIṢ YÜCESAN

Suner, Levent, "Commedia Dell'Arte Etkisinde Üç Oyun Beş Yorum", Tiyatro Araştırmaları Dergisi 24: 2007, 145-182. 